\title{
Perbandingan Perkiraan Debit Banjir Rancangan Menggunakan Data Hujan dan Debit di DAS Kaliwadas Kab. Pekalongan, Jawa Tengah
}

\author{
S. Samatan ${ }^{\mathrm{a} *}$ \\ ${ }^{a}$ Jurusan Teknik Sipil, Fakultas Teknik Universitas Gunadarma, Jakarta \\ *Corresponding author's e-mail: kandi250576@gmail.com
}

Received: 28 July 2020; revised: 10 August 2020; accepted: 10 August 2020

\begin{abstract}
Design flood discharge is one of the important parameters in the management of water resources, especially water resources utilization structures and water damage control structures. This parameter serves to determine the dimensions and capacity of the planned water structures. As an important reference, this design flood discharge must be carefully determined so that the planned building is effective and financially functional and economically efficient. This study aims to determine the design flood discharge using rainfall data which will be recommended as a reference for the design of a micro-hydro power plant building in Kaliwadas River, Pekalongan Regency, Central Java Province. The results of the analysis based on rainfall data are compared with estimates using discharge data to determine deviations resulting from the use of rainfall data. Frequency analysis is applied to both types of rainfall and maximum daily discharge data. Chi-Square and Kolmogorov-Smirnov tests were performed to test four distribution methods: Normal, Normal Log, Pearson Log III and Gumbel. Transformation of design rainfall into design discharge is done using the Snyder Synthetic Unit Hydrograph Method, by first optimizing the hydrograph parameter. The analysis shows that the design flood discharge using rainfall data is relatively lower than using discharge data with an average deviation of more than $15 \%$. This deviation is expected to occur when the transformation of rainfall into discharge is influenced by various very complex parameters, especially changes in land cover and rainfall distribution that have not been fully accommodated. However, for watersheds with very limited discharge data, the use of rain data can be an option for establishing a design flood discharge.
\end{abstract}

Keywords: frequency analysis, watershed, flood peak, hydraulic structure, water resources management.

\begin{abstract}
Abstrak: Debit banjir rancangan merupakan salah satu parameter penting dalam pengelolaan sumber daya air terutama bangunan pemanfaatan sumber daya air dan bangunan pengendali daya rusak air. Parameter ini berfungsi untuk menetapkan dimensi dan kapasitas bangunan keairan yang direncanakan. Sebagai referensi penting, debit banjir rancangan ini harus ditetapkan secara cermat agar bangunan yang direncanakan efektif dan efesien secara fungsi dan ekonomis secara pembiayaan. Penelitian ini bertujuan untuk menetapkan debit banjir rancangan menggunakan data hujan yang akan direkomendasikan sebagai referensi perancangan bangunan pembangkit listrik tenaga mikrohidro di Sungai Kaliwadas, Kabupaten Pekalongan Provinsi Jawa Tengah. Hasil analisis berdasarkan data hujan tersebut dibandingkan dengan perkiraan menggunakan data debit untuk mengetahui penyimpangan yang dihasilkan dari penggunaan data hujan. Analisis frekuensi diterapkan terhadap kedua jenis data hujan dan debit harian maksimum. Uji Chi-Square dan Kolmogorov-Smirnov dilakukan untuk menguji empat metode distribusi: Normal, Log Normal, Log Pearson III dan Gumbel. Transformasi hujan rancangan menjadi debit rancangan dilakukan menggunakan Metode Hidrograf Satuan Sintetik Snyder, dengan terlebih dahulu melakukan optimasi parameter hidrograf. Hasil analisis menunjukkan bahwa debit banjir rancangan menggunakan data hujan relatif lebih rendah dibandingkan menggunakan data debit dengan penyimpangan rata-rata di atas $15 \%$. Penyimpangan ini diperkirakan dapat terjadi pada saat transfromasi hujan menjadi debit yang dipengaruhi oleh beragam parameter yang sangat kompleks, terutama perubahan tutupan lahan dan distribusi hujan yang belum sepenuhnya dapat terakomodasi. Namun demikian, untuk DAS dengan data debit yang sangat terbatas, penggunaan data hujan dapat menjadi pilihan untuk menetapkan debit banjir rancangan.
\end{abstract}

Kata kunci: analisis frekuensi, daerah aliran sungai, puncak banjir, bangunan air, pengeloaan SDA.

\section{Pendahuluan}

Penetapan debit banjir rancangan sebagai parameter dasar untuk pengelolaan sumber daya air umumnya dapat dilakukan menggunakan data debit harian maksimum dengan rentang data memadai. Data debit ini dapat dipeoleh dari stasiun pengukur tinggi muka air (AWLR) di suatu outlet, dengan mengkonversi data AWLR menjadi debit berdasarkan persamaan kurva debit (rating curve) yang bersesuaian dengan alat ukur tersebut [1]. Hasil perkiraan debit banjir rancangan menggunakan data debit tersebut dapat diterima sepanjang data yang diukur terkalibrasi dengan baik dan metode analisis frekuensi yang dipilih sesuai dengan distribusi statistik data [2-6].
Secara umum sebaran alat ukur debit (AWLR) jauh lebih rendah dari alat ulur hujan di berbagai wilayah di Indonesia. Alat ukur hujan hampir terpasang merata di berbagai wilayah, mengingat data ini dimanfaatkan tidak hanya untuk pengelolaan SDA tetapi juga berbagai tujuan seperti pertanian, perkebunan, penerbangan dan lainnya. Oleh karena itu, alat ukur hujan ini tidak hanya dipasang oleh Dinas PU atau SDA tetapi juga oleh Dinas Kehutanan, Dinas Pertanian, BMKG, BPDAS, Balai Sungai dan beberapa instansi lainnya [7-8].

Alat ukur debit umumnya dipasang sangat terbatas, dan hanya berkaitan dengan pengelolaan SDA dan konservasi DAS. Biaya instalasi, operasi dan pemeliharaan alat ini juga jauh lebih tinggi dibandingkan dengan alat ukur hujan. 
Alasan-alasan tersebut dapat menjadi rujukan dalam pemasangan alat ini dengan pertimbangan bahwa alat tersebut benar-benar diperlukan oleh pengelolanya [9-10].

Keterbatasan data debit memberikan peluang penggunaan data hujan untuk analisis debit baik aliran rendah (low flow) maupun aliran puncak (flow peak) termasuk debit rancangan (design flood) [11-14]. Beberapa peneliti telah melakukan kajian dengan menggunakan data hujan untuk memprediksi debit akibat keterbatasan data debit. Pada Tahun 2017, Aurdin melakukan perhitungan debit banjir rancangan di DAS Batara menggunakan data hujan [15]. Transformasi hujan menjadi debit dilakukan dengan menggunakan beberapa metode seperti Hasper, Melchior dan Nakayasu tanpa kalibrasi. Analisis serupa juga dilakukan oleh Sofyan dan Rifai (2017) di DAS Batang [16].

Selanjutnya Sarminingsih (2018) dan Prawati (2018), masing-masing melakukan analisis serupa di Embung Coyo Kabupaten Grobogan Jawa Tengah dan DAS Blambangan Kabupaten Banyuwangi Jawa Timur [17-18]. Penetapan debit banjir rancangan pada kedua sungai tersebut juga menggunakan data hujan tanpa mengetahui kehandalannya. Pada Tahun 2020, analisis debit banjir rancangan dilakukan oleh Haidah dkk, dengan membandingkan beberapa metode [19].

Dari serangkaian analisis yang dilakukan oleh para peneliti-peneliti tersebut, tidak satupun yang melakukan analisis debit banjir rancangan menggunakan data debit atau memverifikasi hasil analisisnya dengan data debit. Oleh karena itu kajian ini akan menjadi penting untuk mengetahui seberapa besar penyimpangan analisis menggunakan data hujan berdasarkan perbandingan dengan data debit. Hasil kajian ini akan sangat berguna sebagai evaluasi penggunaan data hujan untuk analisis hudrologi guna mendukung perancangan dan pengelolaan sumber daya air [20].

\section{Metode Penelitian}

\subsection{Lokasi Penelitian}

Penelitian ini dilaksanakan di Sungai Kaliwadas (Gambar 1), yang terletak di Kecamatan Kandang Serang Kabupaten Pekalongan Provinsi Jawa Tengah. Sungai Kaliwadas merupakan salah sub DAS dengan luas daerah pengaliran kurang lebih $165.78 \mathrm{~km}^{2}$ yang diukur pada Pos hidrometri (AWLR) terdapat pada Bendung Kaliwadas dan Bendung Lambur di sebelah hulu Bendung Kaliwadas.
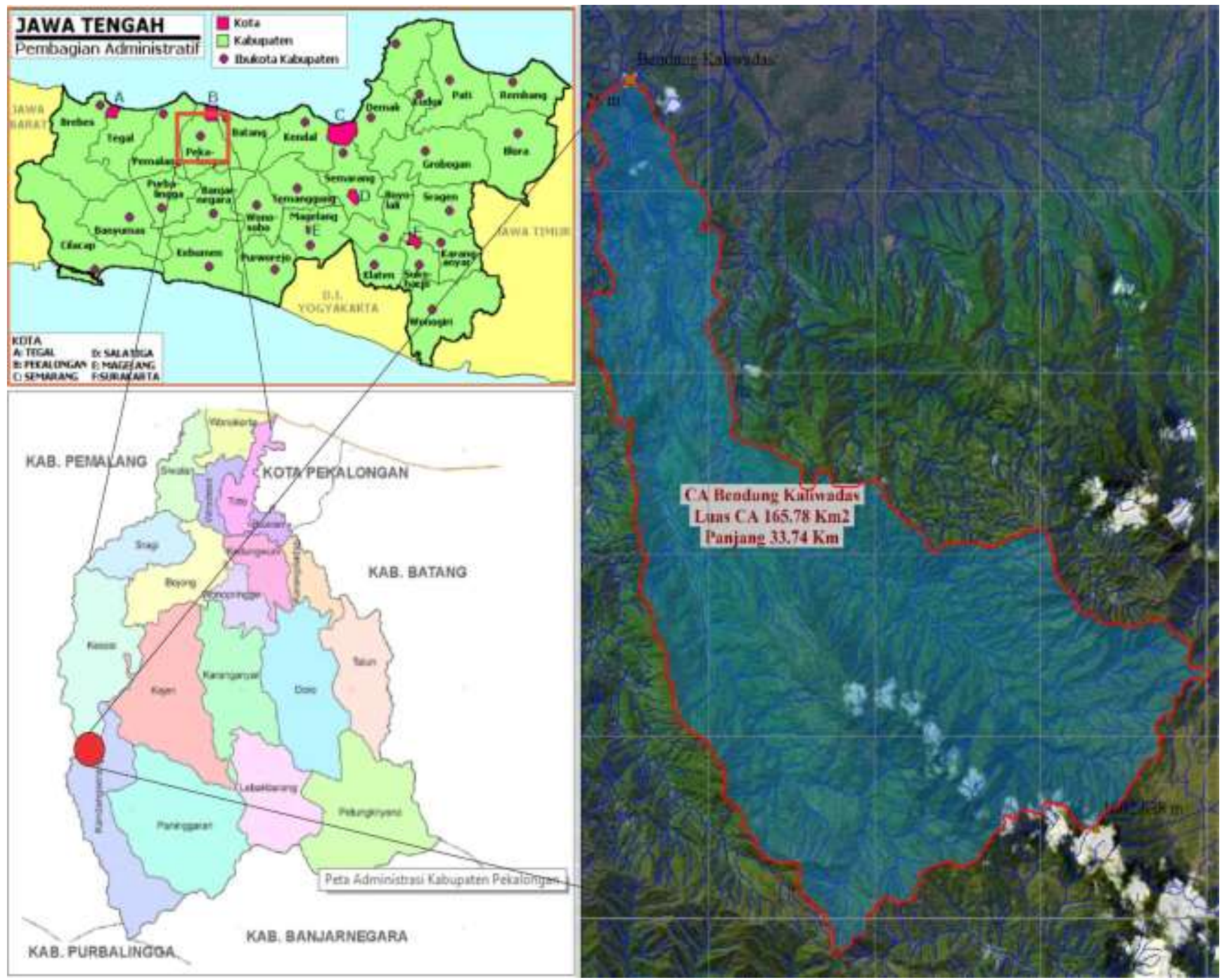

Gambar 1. Peta lokasi penelitian 
Secara geografis, DAS Kaliwadas terletak pada koordinat $116^{\circ} 49^{\prime} 19.2362^{\prime \prime E}-116^{\circ} 55^{\prime} 52.4184^{\prime \prime E}$ dan $41^{\circ} 15^{\prime} 17.9854^{\prime \prime S}-4^{\circ} 21^{\prime} 18.4372$ "S. DAS Kaliwadas memiliki kerapatan jaringan sungai kategori sedang dengan bentuk DAS memanjang dan termasuk dalam kelompok DAS berukuran sedang, dengan topografi berada pada ketinggian 170 m-1800 m DPL. Secara umum tutupan lahan relatif masih terkonservasi terutama pada DAS bagian hulu yang didominasi oleh hutan primer dan sekunder sedangkan pada DAS bagian hilir telah dikembangkan untuk lahan pertanian lahan basah dan lahan kering serta permukiman.

\subsection{Data}

Bahan penelitian yang digunakan pada penelitian meliputi peta DEM, data tutupan lahan, data hujan jamjaman dan harian. Peta tutupan lahan bisa diperoleh dari BAPPEDA Kabupaten Pekalongan sedangkan data hujan dan debit bisa didapatkan dari Balai Wilayah Sungai (BWS) Periode 2009-2018. Data lainnya adalah data ukur debit Pos AWLR Bendung Kaliwadas untuk keperluan kalibrasi.

\subsection{Metode dan Tahapan Penelitian}

Penelitian ini diawali dengan penyeleksian data hujan dan debit harian maksimum yang mewakili masing-masing tahun. Analisis frekuensi diterapkan untuk terhahadap kedua jenis data tersebut menggunakan empat metode distribusi yaitu Normal, Log Normal, Log Pearson Type III dan Gumbel. Persamaan distribusi keempat metode tersebut dapat dinyatakan dengan :

$$
X_{T}=\bar{X}+K_{T} S
$$

dimana:

$X_{T}=$ Curah hujan $(\mathrm{mm})$ atau debit $\left(\mathrm{m}^{3} / \mathrm{s}\right)$ rancangan dengan periode ulang tertentu

$\bar{X}=$ Curah hujan $(\mathrm{mm})$ atau debit $\left(\mathrm{m}^{3} / \mathrm{s}\right)$ rata-rata

$K_{T}=$ Faktor frekuensi yang bersesuaian dengan periode ulang terpilih

$S=$ Standar deviasi dari data

Untuk Distribusi Log Normal dan Log Pearson Type III, data hujan atau debit harian maksimum dinyatakan dalam logaritma $(\log X)$. Faktor frekuensi untuk Distribusi Normal dan Log Normal dapat ditetapkan dari Tabel Standar Normal atau Tabel Reduksi Gauss. Untuk Distribusi Log Pearson, $K_{T}$ dihitung berdasarkan Tabel Faktor Frekuensi untuk Distribusi Log Perason Type III sebagai fungsi dari periode ulang $(T)$ dan koefisien skewness $(C s)$. Faktor frekuensi untuk Metode Gumbel, dinyatakan dengan persamaan:

$$
\begin{aligned}
& K_{T}=\frac{Y_{T}-Y_{n}}{S_{n}} \\
& Y_{T}=-\ln \left\{-\ln \left(\frac{T-1}{T}\right)\right\}
\end{aligned}
$$

dengan:

$$
\begin{aligned}
Y_{n}= & \begin{array}{l}
\text { Reduced mean yang tergantung pada jumlah sampel } \\
\text { atau data } \mathrm{n}
\end{array} \\
S_{n}= & \begin{array}{l}
\text { Reduced standard deviation yang juga tergantung } \\
\text { pada jumlah sampel } \mathrm{n}
\end{array} \\
Y_{t}= & \text { Reduced variate }
\end{aligned}
$$

Langkah selanjutnya adalah pengujian metode distribusi untuk menetapkan distribusi terbaik. Pengujian dilakukan dengan Uji Chi-Square dan Kolmogorov-Smirnov. Persamaan yang digunakan pada kedua jenis uji ini secara berturut-turut dinyatakan dengan:

$$
\begin{aligned}
& \chi^{2}=\frac{\sum\left(o_{f}-E_{f}\right)^{2}}{\sum E_{f}} \\
& \Delta_{m}=\max \left|P_{O}(x)-P_{E}(x)\right|
\end{aligned}
$$

dengan:

$\chi^{2}=$ Chi-Square dari data observasi dan hitungan (ekspektasi)

$O_{i}=$ Frekuensi data pengamatan

$E_{i}=$ Frekuensi data ekspektasi (teoritis)

$\Delta_{m}=$ Parameter Kolmogorov-Smirnov

$P_{i}=$ Probabilitas data pengamatan

$E_{i}=$ Probabilitas data ekspektasi (teoritis)

Nilai $\chi^{2}$ dan $\Delta_{m}$ hasil hitungan dibandingkan dengan nilai $\chi^{2}$ dan $\Delta_{m}$ pada masing-masing tabel uji. Metode distribusi yang memenuhi syarat uji adalah metode yang memiliki nilai $\chi^{2}$ dan $\Delta_{m}$ hasil hitungan lebih kecil dari nilai $\chi^{2}$ dan $\Delta_{m}$ tabel.

Berdasarkan metode distribusi terpilih, maka dapat ditetapkan hujan dan debit rancangan untuk beberapa periode ulang. Selanjutnya hujan rancangan ditransformasi menjadi debit rancangan untuk dibandingkan dengan debit rancangan hasil analisis frekuensi. Transformasi hujan menjadi debit dapat dilakukan menggunakan HSS Snyder. Metode ini dikembangkan oleh Snyder (1938) berdasarkan data parameter DAS di AS (berukuran $30 \mathrm{~km}^{2}-30000 \mathrm{~km}^{2}$ ) dengan menghubungkan tiga parameter penting yaitu tenggang waktu dari titik berat hujan sampai titik berat hidrograf (time lag, $T_{l}$ ), debit puncak $\left(Q_{p}\right)$ dan waktu dasar dari hidrograf $\left(T_{b}\right)$, diformulasikan sebagai $[7,9]$ :

$$
\begin{aligned}
& Q_{p}=0.278\left(\frac{C_{p}}{T_{l}}\right) \mathrm{A} \\
& T_{l}=C_{t}\left(L L_{c}\right)^{\mathrm{n}} \\
& T_{p}=T_{l}+\frac{T_{r}}{2} \\
& T_{b} \approx 5 T_{l}
\end{aligned}
$$

$C_{t}=$ Koefisien tampungan DAS empiris, 0.73-3.0, $L=$ Panjang sungai utama $(\mathrm{km}), L_{c}=$ Panjang sungai dari titik terdekat titik berat DAS ke outlet $(\mathrm{km})$ dan $C_{p}=$ Konstanta empiris (0.9-1.4).

Snyder hanya membuat persamaan empiris untuk menghitung debit puncak $\left(Q_{p}\right)$ dan waktu puncak $\left(T_{p}\right)$. Untuk menghitung ordinat hidrograf dilakukan pendekatan perhitungan menggunakan $W_{50}$ dan $W_{75}$ seperti ditunjukkan pada Gambar 2. Cara ini memiliki kelemahan berkaitan dengan bentuk hidrograf yang tidak sempurna (wajar) dan untuk mendapatkan lengkung hidrograf pada titik-titik yang lain memerlukan waktu untuk mengkalibrasi parameterparameternya [7,9]. Untuk mengatasi permasalahan tersebut, Alexejev mengusulkan persamaan hidrograf satuan untuk HSS Snyder sebagai berikut:

$$
Q=f(t)
$$




$$
\begin{aligned}
& Y=\frac{Q}{Q_{p}}, X=\frac{t}{T_{p}} \\
& Y=10^{-a \frac{(1-X)^{2}}{X}} \\
& a=1.32 \lambda^{2}+0.15 \lambda+0.045 \\
& \lambda=\frac{Q_{p}}{h} \frac{T_{p}}{A}
\end{aligned}
$$

$X$ dan $Y$ adalah koordinat hidrograf, dan $h=$ tinggi hujan satuan sebesar $1 \mathrm{~mm}$.

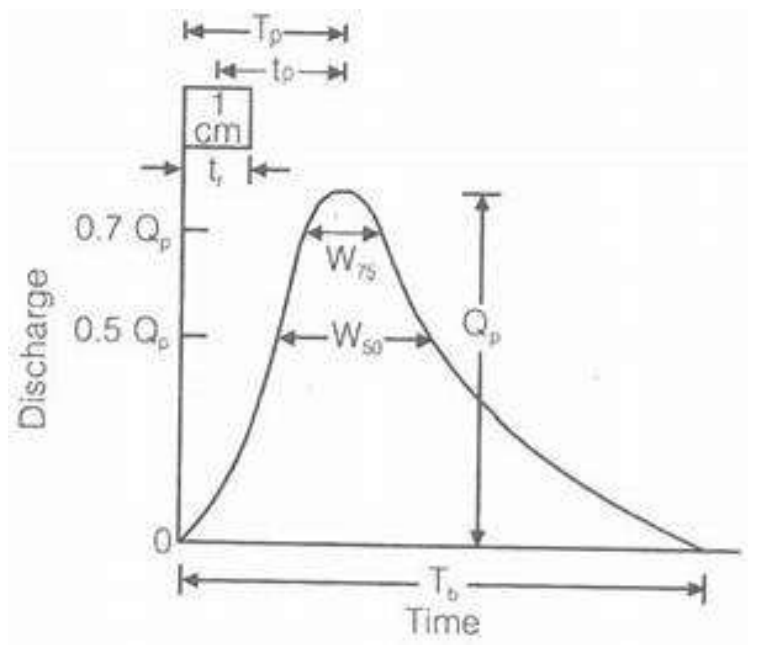

Gambar 2. Peta lokasi penelitian

Hasil perkiraan debit rancangan menggunakan transformasi hidrograf ini, selanjutnya dibandingkan dengan debit rancangan hasil dari analisis frekuensi. Evaluasi ini menggunakan Mean Absolute Error (MAE), berdasarkan persamaan berikut:

$$
P(\%)=\left|\frac{Q_{h}-Q_{d}}{Q_{d}}\right| 100 \%
$$

dengan:

$P=$ Penyimpangan (\%)

$Q_{h}=$ Debit rancangan berdasarkan data hujan menggunakan trasnformasi hidrograf

$Q_{h}=$ Debit rancangan berdasarkan data debit menggunakan analisis frekuensi.

\section{Hasil dan Pembahasan}

\subsection{Pemilihan Data Hujan dan Debit}

Data hujan dan debit harian Periode 2009-2019 diseleksi dengan pendekatan Annual Maximum Series. Data terpilih didasarkan pada data harian maksimum pada masingmasing tahun. Menggunakan cara ini diperoleh sejumlah data hujan dan debit maksimun seperti pada Gambar 3.

Pada Gambar 3 terlihat kecenderungan hubungan antara data hujan dan debit harian maksimum. Secara umum terdapat kesesuaian cukup baik dengan angka korelasi 0.70. Namun bila dicermati lebih lanjut terlihat kontradiksi antara hujan dan debit pada Tahun 2012 dimana hujan harian relatif sangat tinggi hampir mencapai $200 \mathrm{~mm} /$ hari sedangkan debit harian rata-rata justru mendekati debit terkecil. Kemungkinan-kemungkinan tersebut dapat saja terjadi sehubungan dengan kompleksitas faktor hujan dan
DAS serta keterbatasan alat ukur yang sangat sensitif terhadap kondisi lingkungan sekitarnyanya.

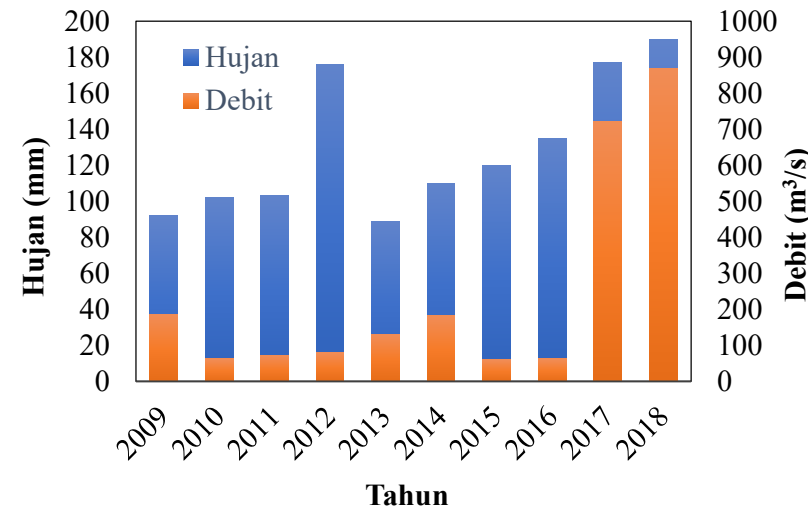

Gambar 3. Data hujan dan debit harian maksimum

\subsection{Pemilihan Metode Distribusi}

Sebagaimana telah dituliskan sebelumnya bahwa metode distribusi yang diaplikasikan pada kajian ini terdiri dari Normal, Log Normal. Log Pearson Type III dan Gumbel. Berdasarkan pengujian statistik terhadap keempat metode tersebut baik untuk data hujan dan debit, nampak bahwa semua metode memenuhi Uji Kolmogorov-Smirnov. Untuk uji Chi-Square semua metode memenuhi syarat pada data hujan, sedangkan pada data debit hanya Metode Log Normal dan Log Pearson III yang memenuhi . Berdasarkan kedua uji tersebut Metode Log Pearson III memperlihatkan kinerja terbaik dengan selisih $\chi^{2}$ dan $\Delta_{m}$ terbesar, walaupun

\begin{tabular}{|c|c|c|c|c|}
\hline \multirow[b]{2}{*}{ Uji } & \multicolumn{4}{|c|}{ Metode Distribusi } \\
\hline & Normal & $\begin{array}{c}\text { Log } \\
\text { Normal }\end{array}$ & $\begin{array}{c}\text { Log } \\
\text { Pearson } \\
\text { III } \\
\end{array}$ & Gumbel \\
\hline$\chi_{h i t}^{2}$ & 2 & 2 & 2 & 2 \\
\hline$\chi_{c r i}^{2}$ & 5.991 & 5.991 & 5.991 & 5.991 \\
\hline Keterangan & lolos & lolos & lolos & lolos \\
\hline$\Delta_{m}$ & 0.162 & 0.160 & 0.156 & 0.162 \\
\hline$\Delta_{c r i}$ & 0.410 & 0.410 & 0.410 & 0.410 \\
\hline Keterangan & lolos & lolos & lolos & lolos \\
\hline \multicolumn{5}{|c|}{ Tabel 2. Rekapitulasi uji statistik data debit } \\
\hline \multirow[b]{2}{*}{ Uji } & \multicolumn{4}{|c|}{ Metode Distribusi } \\
\hline & Normal & $\begin{array}{l}\text { Log } \\
\text { Normal }\end{array}$ & $\begin{array}{l}\text { Log } \\
\text { Pearson } \\
\text { III }\end{array}$ & Gumbel \\
\hline$\chi^{2}$ hit & 12 & 3 & 3 & 9 \\
\hline$\chi_{c r i}^{2}$ & 5.991 & 5.991 & 5.991 & 5.991 \\
\hline Keterangan & tidak & lolos & lolos & tidak \\
\hline$\Delta_{m}$ & 0.303 & 0.175 & 0.139 & 0.239 \\
\hline$\Delta_{c r i}$ & 0.410 & 0.410 & 0.410 & 0.410 \\
\hline Keterangan & lolos & lolos & lolos & lolos \\
\hline
\end{tabular}
pada Uji Chi-Square memperlihatkan selisih $\chi^{2}$ seragam pada data hujan. Hasil uji kedua metode tersebut disajikan pada Tabel 1 dan Tabel 2.

Tabel 1. Rekapitulasi uji statistik data hujan

Khusus untuk hasil uji pada Tabel 1, sesungguhnya semua metode distribusi dapat diterapkan walaupun 
parameter statistiknya cenderung tidak mendekati salah satu metode manapun. Namun demikian mengingat bahwa dari kedua uji Chi-Square dan Kolmogorov-Smirnov, Metode Log-Pearson III memperlihatkan kinerja terbaik maka metode ini akan diterapkan untuk analisis hujan dan debit rancangan.

\subsection{Hujan dan Debit Rancangan}

Hujan dan debit rancangan menggunakan Metode Log Pearson III, adalah seperti pada Gambar 4. Plotting posisi metode ini pada kertas probabilitas untuk data hujan dapat dilihat pada Gambar 5.

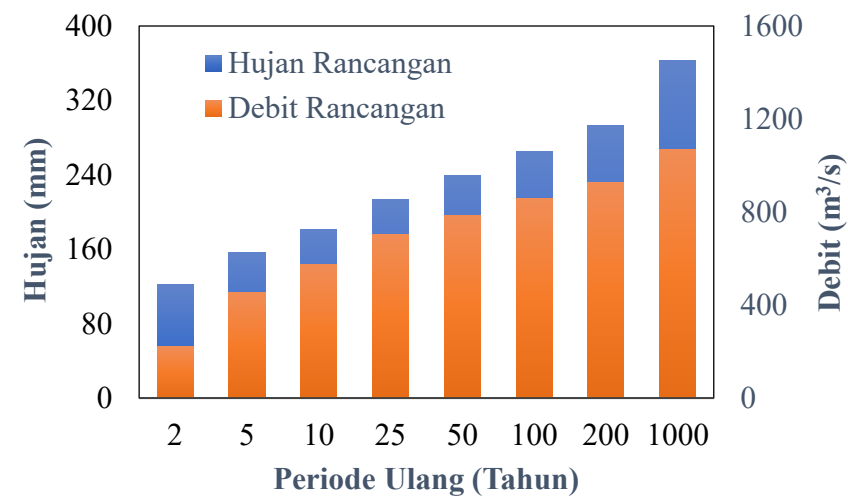

Gambar 4. Hujan dan debit rancangan
Nampak bahwa kenaikan hujan terhadap periode ulang memperlihatkan perbedaan trend. Kenaikan hujan terhadap periode ulang cenderung mengikuti kurva geometrik sedangkan peningkatan debit terhadap periode ulang cenderung mengikuti kurva eksponensial. Walaupun demikian perbedaan trend hanya terlihat secara nyata pada periode ulang yang besar (100-1000).

\subsection{Transformasi Hujan}

Transformasi hujan rancangan menjadi banjir rancangan dilakukan dengan Metode Snyder. Metode ini umumnya sering diterapkan di Indonesia untuk berbagai tujuan seperti perencanaan bangunan air (bendung dan waduk) dan pengendalian banjir. Transformasi hujan-debit menggunakan metode ini, memerlukan data karaktersitik DAS yang diturunkan dari data DEM dan data tata guna lahan yang diinterpretasi dari citra landsat. Data terakhir ini digunakan untuk menetapkan koefisien limpasan sebagai faktor penentu limpasan permukaan dan infiltrasi.

Berdasarkan kenampakan citra sebagaimana ditunjukkan pada Gambar 1, secara umum DAS Kaliwadas masih terliput oleh tutupan lahan berupa hutan dengan kerapatan sedang sampai tinggi terutama pada bagian hulu. Untuk segmen tengah dan hilir, kerapatan vegetasi cenderung berkurang bahkan tampak adanya konversi lahan untuk tanaman budidaya pertanian.

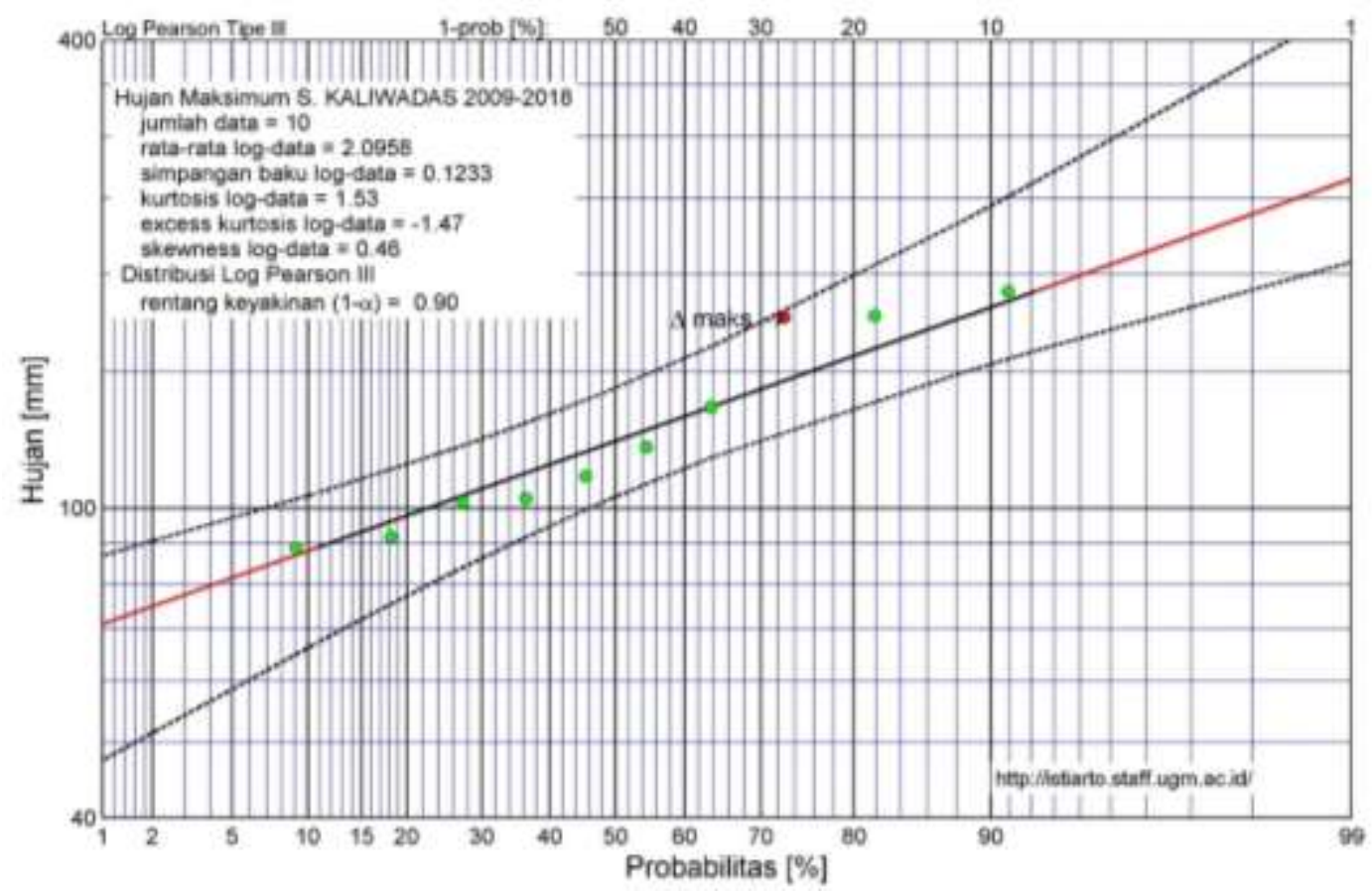

Gambar 5. Kertas probabilitas data hujan harian maksimum Sungai Kaliwadas

Dampak dari konversi lahan ini adalah meningkatnya intensitas dan besaran banjir sebagaimana ditampilkan pada Gambar 3, pada tahun 2017 dan 2018, terjadi peningkatan debit banjir yang sangat signifikan. Perubahan tutupan lahan ini diakomodasi pada persamaan Snyder yang dinyatakan dengan koefisien limpasan.

Hal terpenting lainnya dalam transformasi hujan ini adalah intensitas hujan [7,9]. Hujan rancangan yang diperoleh dari analisis frekeuensi dikonversi menjadi hujan jam-jaman yang cocok untuk daerah tersebut. Beberapa kajian menyebutkan bahwa untuk area di Pulau Jawa Metode Alternating Block Method (ABM) dan Mononobe cenderung sesuai [7]. Kedua metode ini sebenarnya mempunyai kemiripan dalam intensitas tetapi berbeda dalam hal pola. Metode ABM mempunyai puncak intensitas hujan di tengah durasi hujan sedangkan Metode Mononobe, intensitas hujan berpuncak di awal durasi. Gambar 6 menyajikan hasil transformasi hujan menjadi debit. 


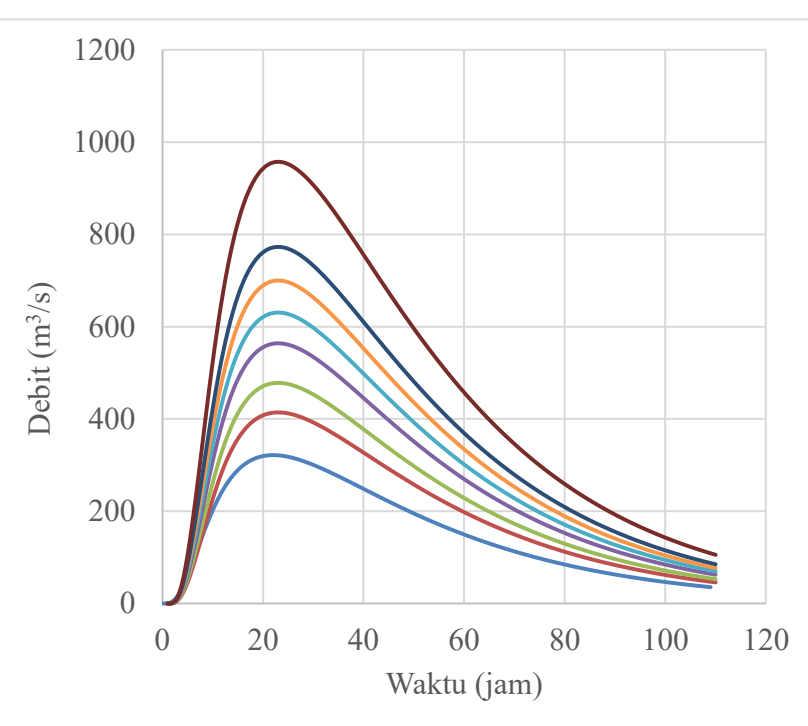

Gambar 6. Debit hasil transformasi hujan menggunakan Metode Snyder

\subsection{Perbandingan Debit}

Hasil analisis debit menggunakan data hujan dan debit sebagaimana telah diuraikan pada seksi sebelumnya, dapat dibuat perbandingan dan di analisis penyimpangannya sesuai dengan Tabel 3.

Tabel 3. Perbandingan dan penyimpangan debit rancangan

\begin{tabular}{|c|c|c|c|}
\hline \multirow{2}{*}{$\begin{array}{c}\text { Periode } \\
\text { Ulang } \\
\text { (Tahun) }\end{array}$} & \multicolumn{2}{|c|}{ Debit rancangan $\left(\mathrm{m}^{3} / \mathrm{s}\right)$} & \multirow[b]{2}{*}{$\begin{array}{c}\text { Penyimpangan } \\
(\%)\end{array}$} \\
\hline & $\begin{array}{c}\text { Analisis } \\
\text { Frekuensi }\end{array}$ & $\begin{array}{c}\text { Transformas } \\
\text { i Hidrograf }\end{array}$ & \\
\hline 2 & 223.40 & 321.83 & 44.06 \\
\hline 5 & 453.40 & 413.98 & 8.69 \\
\hline 10 & 573.60 & 478.34 & 16.61 \\
\hline 25 & 701.80 & 563.74 & 19.67 \\
\hline 50 & 784.60 & 630.45 & 19.65 \\
\hline 100 & 859.10 & 699.92 & 18.53 \\
\hline 200 & 927.20 & 772.76 & 16.66 \\
\hline 1000 & 1067.80 & 957.54 & 10.33 \\
\hline \multicolumn{3}{|c|}{ Penyimpangan rata-rata } & 19.27 \\
\hline
\end{tabular}

Sebagaimana tampak pada Tabel 3, penyimpangan debit hasil prediksi menggunakan data hujan bervariasi antara 8$45 \%$. Semakin tinggi periode ulang penyimpangan debit cenderung berkurang. Penyimpangan besar terjadi pada periode ulang rendah. Namun demikian penyimpangan ratarata yang dihasilkan adalah sebesar 19.27\% tergolong transisi sedang. Oleh karena itu dalam aplikasi penggunaan data hujan untuk memprediksi debit harus dilakukan dengan hari-hati terutama dalam proses transformasi hujan-debit.

\section{Kesimpulan}

Perkiraan debit banjir rancangan telah dilakukan berdasarkan data hujan dan debit menggunakan analisis frekuensi dan transformasi hidrograf berdasarkan data hujan dan debit harian maksimum Periode 2009-2018 di Sungai Kaliwadas. Hasil analisis menunjukkan bahwa debit banjir rancangan menggunakan data hujan relatif lebih rendah dibandingkan menggunakan data debit dengan penyimpangan rata-rata di atas $15 \%$. Penyimpangan ini diperkirakan dapat terjadi pada saat transfromasi hujan menjadi debit yang dipengaruhi oleh beragam parameter yang sangat kompleks, terutama perubahan tutupan lahan dan distribusi hujan yang belum sepenuhnya dapat terakomodasi. Namun demikian, untuk DAS dengan data debit yang sangat terbatas, penggunaan data hujan dapat menjadi pilihan untuk menetapkan debit banjir rancangan.

\section{Daftar Pustaka}

[1] M.Y. Talumepa, L. Tanudjaja, and J.S.F. Sumarauw, "Analisis Debit Banjir dan Tinggi Muka Air Sungai Sangkub Kabupaten Bolaang Mongondow Utara", Jurnal Sipil Statik, vol. 15, no. 10, p. 699, 2017.

[2] M.S. Bhat, A. Alam, B. Ahmad, B.S. Kotlia, H. Farooq, A.K. Taloor, and S. Ahmad, "Flood Frequency Analysis of River Jhelum in Kashmir Basin”, Quaternary International, vol. 507, p. 288, 2018

[3] T.A. Gado, K. Hsu, and S. Sorooshian, "Rainfall Frequency Analysis for Ungauged Sites Using Satellite Precipitation Products", Journal of Hydrology, vol. 554, p. 646, 2017.

[4] A.A. Mamoon, and A. Rahman, "Selection of The Best Fit Probability Distribution in Rainfall Frequency Analysis for Qatar", Natural Hazards, vol. 86, p. 281, 2016.

[5] V. Rajendran, and R. Venkatasubramani, "Frequency Analysis of Rainfall Deviation in Dharmapuri District in Tamil Nadu", Indian Journal of Geo Marine Sciences, vol. 46, no. 8, p. 1710, 2017.

[6] N. Bhagat, "Flood Frequency Analysis Using Gumbel's Distribution Method: A Case Study of Lower Mahi Basin, India", Journal of Water Resources and Ocean Science, vol. 6, no. 4, p. 51, 2017.

[7] B. Triatmodjo, Hidrologi Terapan, Jilid 1. Yogyakarta: Beta Offset, 2010.

[8] D. Fitriani, P. Satriyo, and Devianti, “Analisis Debit Rencana Metode Rasional di Sub DAS Lawe Simpali Kabupaten Aceh Selatan", Jurnal Ilmiah Mahasiswa Pertanian, vol. 5. No. 1, 2020.

[9] S.H. Brotowiryatmo, Hidrologi, Teori, Masalah, Penyelesaian, Jilid 1. Yogyakarta: Nafiri Offset, 2000.

[10] A. Herison, Y. Romdania, O.T. Purwadi, and R. Effendi, "Kajian Penggunaan Metode Empiris dalam Menentukan Debit Banjir Rancangan pada Perencanaan Drainase (Review)", Jurnal Aplikasi Teknik Sipil, vol. 16, no. 2, p. 77, 2018.

[11] G. Gunawan, Besperi, and L. Purnama, "Analisis Debit Banjir Rancangan Sub DAS Air Bengkulu Menggunakan Analisis Frekuensi dan Metode Distribusi”, Jurnal Ilmiah Rekayasa Sipil, vol. 17, no. 1, p. 1, 2020.

[12] N. Sahrani, and R. Hotter, "Analisis Curah Hujan Dalam Mengidentifikasi Potensi Batang Lumpo Untuk 
PLTMH", UNES Journal of Scientech Research, vol. 3, no. 2, p. 119, 2018.

[13] D. Mayasari, “Analisa Statistik Debit Banjir dan Debit Andalan Sungai Komering Sumatera Selatan”, Jurnal Forum Mekanika, vol. 6, no. 2, 2017.

[14] S.N. Purnomo, "Pengaruh Metode Pemilihan Data Hujan Pada Perancangan Debit Banjir di Das Serayu", Techno, vol. 18, no. 1, p. 50, 2017

[15] Y. Aurdin, "Perbandingan Perhitungan Debit Banjir Rancangan di DAS Betara Dengan Menggunakan Metode Hasper, Melchior dan Nakayasu", Teknika: Jurnal Teknik, vol. 3, no. 2, p. 192, 2017.

[16] Z. Syofyan, and M.C. Rifa'i, “Analisis Curah Hujan Untuk Pendugaan Debit Banjir Pada DAS Batang Arau Padang", Menara Ilmu, vol. 12, no. 1, p. 154, 2018.
[17] A. Sarminingsih, "Pemilihan Metode Analisis Debit Banjir Rancangan Embung Coyo Kabupaten Grobogan", Jurnal Presipitasi : Media Komunikasi dan Pengembangan Teknik Lingkungan, vol. 15, no. 1, p. 53, 2018.

[18] E. Prawati, "Analisis Hujan Rata-Rata Dalam Menentukan Debit Banjir Rancangan Pada DAS Blambangan Kabupaten Banyuwangi Jawa Timur", TAPAK, vol. 9, no. 1, 2019.

[19] H. Saidah, A. Pracoyo, and Khairudin, "Perbandingan Beberapa Metode Perhitungan Debit Puncak Banjir Rancangan", Ganec Swara, vol. 14, no. 1, p. 526, 2020.

[20] A.J. Sutrisno, Kaswanto, and H.S. Arifin, "Prediction and Correlation Analysis between Water Discharge and Rainfall in Ciliwung River, Bogor City", Journal of Natural Resources and Environmental Management, vol. 10, no. 1, p. 25, 2020. 
This page is intentionally left blank 